\title{
The paradoxical occurrence of oolitic limestone on the eastern islands of Great Bahama Bank : where do the ooids come from ?
}

\author{
PASCAL KINDLER ${ }^{1}$ and ALBERT C. HINE $^{2}$ \\ ${ }^{1}$ Section of Earth Sciences, University of Geneva, Maraîchers 13, 1205 Geneva, Switzerland \\ ${ }^{2}$ College of Marine Science, University of South Florida, St. Petersburg, FL 33701, USA
}

\begin{abstract}
The origin of the ooids forming the bulk of many large Pleistocene and Holocene ridges on the windward islands of Great Bahama Bank is not well understood. A formation locus situated to the east of these islands would be consistent with present-day sediment fluxes, but outer platforms in these areas are extremely narrow today and appear unsuitable for largescale ooid production. The four models presented hereafter suggest that ooids could originate (1) from these narrow outer platforms, (2) from wider outer platforms that no longer exist, (3) from the bank interior via tidal channels, and (4) directly from the bank interior by means of a westerly sediment flux. With the exception of option \#3, all models are validated by field observations in Eleuthera and in the Exumas. Corroboration of models \#2 (outer platform erosion) and \# 4 (westerly flux) further indicates that past depositional environments and sedimentary processes on Great Bahama Bank could have been significantly different from those operating today.
\end{abstract}

Keywords Great Bahama Bank, Eleuthera, Exumas, Quaternary, ooids, oolites, eolianites 


\section{INTRODUCTION}

The main thing the first author learned from R.N. Ginsburg during his tenure at the University of Miami in the early 1990's was that the fundamental duty of a scientist is to constantly ask pertinent questions to himself and to others. One of the questions raised by Ginsburg, at that time, was about the paradoxical occurrence of extensive Pleistocene oolites on the windward islands of Great Bahama Bank (GBB; Fig. 1). The petrographic composition of these ridges is, indeed, peculiar because there is no obvious source of ooids, unless sediment fluxes were opposite to those operating today. This paradox is addressed in the following chapters after a brief review of the formation of ooids on GBB, of the sediment transport vectors in the Bahamas, and of the surficial geology of the windward islands.

\section{SETTING}

\section{Ooid production on Great Bahama Bank}

Nearly all authors (Newell et al. 1960; Richter, 1983; Scholle \& Ulmer-Scholle, 2003) agree that conditions required for the optimal production of Bahamian ooids (i.e. aragonitic ooids with a tangential crystal structure) are: (1) the presence of sedimentary particles that can serve as nuclei; (2) a flat topography where these particles can remain for a substantial amount of

time; (3) an environment affected by strong bottom currents where grains can be repeatedly rotated; (4) conditions suitable to inorganic and/or microbial precipitation, for example areas where cool oceanic water mixes with warm bank water supersaturated with respect to aragonite. Modern tangential ooids are preferentially generated in intertidal and shallow subtidal environments along platform edges, such as tidal deltas, lagoons, beaches or tidal flats (Siewers, 2003).

On GBB, ooid sands are forming in platform margin shoals that are parallel to the slope break (Ball, 1967; Harris, 1979; Ginsburg 2005). Most significant modern examples 
include the region south of Bimini $(70 \times 2 \mathrm{~km})$, the southwest end (or Cul-de-Sac) of the Tongue of the Ocean (100 x 20-25 km), the Schooners Cays (45 x $15 \mathrm{~km})$, the Berry Islands (12 x $6 \mathrm{~km})$ and the Joulters Cays (25 x 1-2 km) (Fig. 1). In most of these areas, the ooid factory covers a significant portion of the platform, but in the Joulters Cays, ooids are produced in a 1-2 km-wide mobile fringe juxtaposed to the island and situated only $5 \mathrm{~km}$ bankwards from the slope break (Harris, 1979). Modern ooid accumulations are located in or near the environment where ooids are produced, but the common occurrence of these grains in eolianites (Kindler \& Hearty, 1996) and in deep-water turbidites (Haak \& Schlager, 1989) indicates that significant transportation may take place.

\section{Sediment transport vectors on Great Bahama Bank}

The main physical parameters controlling sediment distribution on the GBB are the wind, wind-induced waves and currents, and tidal currents. In the Bahamas, prevailing winds are from northeast to southeast during most of the year (Sealey, 1994), with strong northwesterly winds, related to cold fronts, further affecting the area in the winter. In addition, gusts associated with thunderstorms can blow in any direction. Winds transport marine sand concentrated in bars and beaches onto or off the islands (Ball, 1967; McKee \& Ward, 1983). In the first case, grains build up coastal dunes that are preserved as eolianites, and increase the island volume. In the second case, sand is washed back into the sea and may possibly be exported to a deeper depositional setting. Winds further generate waves and currents that determine the subaqueous transport of sediment and the distribution of sedimentary bedforms on GBB (Purdy, 1963; Swart et al., this volume; Reijmer et al., this volume). Predominant water movement and sediment transport is thus towards the west, but residual southward and eastward motion takes place during northwesterly gales in the winter (Bathurst, 1975). The influence of tropical storms and hurricanes is less well constrained. Harris (1979) noted that 
most storms affecting the northern Bahamas produce a dominant bankward wind on northeast-facing shorelines, and that associated water movement and sediment transport is also towards the platform interior. In contrast, Boss \& Neumann (1993) observed that Hurricane Andrew had a minimal impact on both subaqueous sand bodies and islands. With the exception of channels between islands, shoals or reefs, tidal currents on and off GBB are sluggish and their influence on the net lateral transport of sand-sized sediments appears to be complex (Gonzalez \& Eberli, 1997). The usual greater velocity of the flood current (Bathurst, 1975) suggests that net sediment transport must be bankward. In summary, due to the predominance of easterly winds, the main sediment transport vector on GBB, today, is from east to west.

\section{The windward islands}

According to Ball (1967), the prevailing easterly winds are responsible for the existence of islands along the eastern edge of GBB (Fig. 1), because they generate sustained wave action that provides "building material" for the constituent dunes. These islands (Eleuthera, Cat, Long, Exumas; Fig. 1) are narrow ( $<1 \mathrm{~km}$ to $12 \mathrm{~km}$ wide), elongated (up to $140 \mathrm{~km}$ ) rock bodies, lying near ( $<1 \mathrm{~km}$ to $7 \mathrm{~km}$ ) the bank margin and oriented parallel to it. They consist of vertically stacked or laterally juxtaposed carbonate units and paleosols (Fig. 2). The former accumulated during interglacial highstands of sea level, whereas the latter developed mostly during glacial lowstands (Carew \& Mylroie, 2001). Details on the stratigraphy of the Bahamian islands can be found in Kindler \& Hearty (1997) and Hearty \& Kaufman (2000). Carbonate units are essentially composed of eolian sediments, but marine deposits, recording ancient sea stands, occur up to $18 \mathrm{~m}$ above modern sea level (Hearty et al., 1999; Kindler \& Hearty, 2000). Eolianite foresets dip always towards the interior of islands, 
emphasizing further that the source material for these dunes originates from the shore and that only onshore winds are effective in dune build up (MacKenzie, 1964; Ball, 1967).

The eastern coasts of the windward islands display locally high (> $20 \mathrm{~m})$ cliffs composed of vertically stacked eolianites showing a consistent landward dip (e.g., northern and central Eleuthera; Fig. 2). These cliffs, which may stand less than $1 \mathrm{~km}$ from the bank edge (e.g., Glass Window area in northern Eleuthera), have long been thought to be primarily composed of oolite. No ooids are presently forming on these narrow outer platforms, which raises the question of the origin of the dune constituent grains. This problem was partly tackled by Kindler \& Hearty $(1995,1996)$ who demonstrated that a significant fraction of these eolianites actually consists of skeletal particles that were likely derived from marginal reefs. Nonetheless, there are elevated oolitic ridges on the windward islands, the highest being Mount Alvernia (63 m) on Cat, and the origin of the constituent ooids is still a puzzle. This enigma is addressed in the following sections.

\section{METHODS}

The geometry, the stratigraphy and the sedimentology of Bahamian carbonate units were essentially studied in the field. Particular attention was given to physical sedimentary structures that provide indications on sediment transport vectors and past depositional environments. Qualitative and quantitative (point counting) petrographic analyses were performed at the University of Geneva to characterize the composition of each studied unit. Samples were sent to various laboratories for relative (amino-acid racemization method) and

absolute $\left({ }^{14} \mathrm{C}\right.$ and U-series techniques) dating. Details on the utilized methods can be found in Kindler \& Hearty (1996) and Hearty \& Kaufman (2000).

\section{MODELS OF OOLITE DEPOSITION ON THE WINDWARD ISLANDS OF GBB}


Four models could explain the peculiar occurrence of Pleistocene and Holocene oolites on the windward islands of GBB. They are presented and discussed in the next chapters.

\section{Ooid production on a narrow outer platform}

In the first model, derived from the modern example along the eastern shoreline of Joulters Cays (Harris, 1979), ooids were produced just offshore, on the narrow (2-5 km) outer shelf, and transported westward onto the islands by the prevailing easterly winds. An example is the eolian ridge exposed at East End Point, on the southernmost tip of Eleuthera (Fig. 3). Already pictured by Ball (1967) and McKee \& Ward (1983), this partly eroded, SSE trending, 15-m high ridge consists of several coalesced haystack dunes showing meter-scale eolian foresets with a predominant westward dip (Fig. 4). The ridge stands less than $4 \mathrm{~km}$ away from the edge of the bank which supports numerous patch reefs. It consists of moderately lithified oolitic-peloidal grainstone (Fig. 5), in striking contrast to modern beach sand which essentially includes bioclastic particles derived from the offshore reefs. These dunes have not been dated, but the absence of an overlying terra-rossa paleosol and their lithological

resemblance with similar, ${ }^{14} \mathrm{C}$-dated eolianites from San Salvador (Carew \& Mylroie, 1987) and Lee Stocking Island (Kindler, 1992) strongly suggest that they are of middle Holocene age.

The westward dip of the ridge foresets (Fig. 4) leaves no doubts on the provenance of the constituent sediments. In addition, the probably young age ( $\sim \mathrm{ka}$ ) of this eolianite implies that the geometry of the bank edge was much the same during the production of the dune particles as today. Thus, the ooids forming the bulk of the East End Point ridge were probably directly generated on the adjacent beach or on a mobile fringe just offshore, as is the case near the Joulters Cays today. Ooid production stalled during the late Holocene, probably because of increasing water depth on the outer platform due to the ongoing transgression. Nonetheless, 
this depositional system was able to build up a 15-m high oolitic ridge in about 1700 years, i.e. between the onset of open marine conditions on the bank about $4.7 \mathrm{kyr}$ ago (Hine, 1983) and the end of ooid production about 3 kyr ago (Kindler, 1992, 1995). This oolitic ridge was then preserved due to the rapidity and efficiency of fresh-water cementation processes (Halley \& Harris, 1979; Kindler \& Mazzolini, 2001).

To determine if it was at all possible to generate sufficient oolitic sand on a narrow shelf during a high-frequency sea-level event, we present the following simple assumptions and calculations. Based upon field observations, we assume that each Pleistocene cycle would produce a $6 \mathrm{~m}$ thick eolian deposit that would extend $1 \mathrm{~km}$ across an island such as Eleuthera. This produces a volume of $6,000 \mathrm{~m}^{3}$ if we make our cross section to be $1 \mathrm{~m}$ wide. Now let's assume that the adjacent shelf was $1 \mathrm{~km}$ wide and oolitic sediments were generated over a 6,000 yr time frame before production shuts down. Sea-level curves indicate that the narrow (1 km wide) shelves fronting much of Eleuthera Island, for example, were flooded since $6 \mathrm{kyr}$ or earlier. Thus, $6,000 \mathrm{~m}^{3}$ of sediment would have to be produced across a strip on the shelf that is $1 \mathrm{~km}$ by $1 \mathrm{~m}$ or $1,000 \mathrm{~m}^{2}$ over 6,000 years, or $1,000 \mathrm{~m}^{3} / 1000$ yr over this same strip of shelf. This converts to $1 \mathrm{~m}^{3} / \mathrm{yr}$ over $1,000 \mathrm{~m}^{2}$ and further converts to $0.001 \mathrm{~m}^{3} / \mathrm{yr} / \mathrm{m}^{2}$. So, how thick is $0.001 \mathrm{~m}^{3}$ when spread over $1 \mathrm{~m}^{2}$ ? By converting to $\mathrm{cm}$, it is $0.1 \mathrm{~cm}$. So, we need a production rate of $0.1 \mathrm{~cm} / \mathrm{yr}$ over a $1 \mathrm{~km}$ wide shelf for 6,000 years. Can oolitic sediments be generated this fast? According to Schlager (1981), such sediments can be produced at rates ranging from $\sim 40$ to $\sim 110 \mathrm{~cm} / 1000 \mathrm{yr}$. To make the calculations simpler, let's choose 100 $\mathrm{cm} / 1000$ yr or $0.1 \mathrm{~cm} / \mathrm{yr}$ - the same number we just calculated. So, based upon this exercise, it is possible for a $1 \mathrm{~km}$ wide shelf to produce sufficient oolitic sediment to generate a realistically sized dune deposit on the adjacent island, assuming efficient transport mechanisms are in place. However, if the oolitic generation phase were significantly condensed temporally and spatially to only 1,000 years and 100 m wide, then a thickness of 6 
$\mathrm{cm} / \mathrm{yr}$ needs to be generated. This is about 60 times faster than the fastest rate reported by Schlager (1981). Perhaps, this scenario is unrealistic? Perhaps, Schlager’s (1981) numbers are incorrect? Perhaps, there is another model that needs to be considered? Nevertheless, it does appear possible to create the sediment from the immediately adjacent shelf.

\section{Ooid production on a wider platform that has since collapsed}

In the second model, based on the present-day example along the Berry Islands where the outer platform is over $15 \mathrm{~km}$ wide (Fig. 1), ooids were formed on a wide outer shelf, which no longer exists, and carried onto the islands by the easterly trade winds. Such a carbonate factory could have been more efficient than the one of the first model because of a more extensive production area. It would thus better explain the occurrence of the large oolitic

ridges forming the backbone of the windward islands. One good example is the Gregory Town ridge in the northern/central part of Eleuthera (Fig. 6). This massive, NW-SE trending crest is $8 \mathrm{~km}$ long, $1.5 \mathrm{~km}$ wide and culminates at about $55 \mathrm{~m}$. It is parallel to the Eleuthera shoreline and its top stands less than $2 \mathrm{~km}$ away from the present-day platform margin, which shows a scalloped (i.e. convex bankward) morphology in this area (Fig. 7; Mullins \& Hine, 1989; Mullins et al., 1991). On the ocean side of the island, the ridge comprises well-exposed subtidal and beach deposits up to $4 \mathrm{~m}$ above mean sea level. In contrast, only eolian sediments, which locally display rainfall-induced fenestral porosity (Bain \& Kindler, 1994; Kindler \& Strasser, 2000), can be seen at higher elevations and on the bank side. The Gregory Town ridge consists of fine-grained, well-lithified oolitic grainstone characterized by the predominance of "normal” (i.e. thickly coated) ooids (Fig. 8). Amino-acid ratios obtained from ridges of identical lithology and stratigraphic position on Eleuthera (Hearty, 1998) and San Salvador (Hearty \& Kindler, 1993), the occurrence of an overlying terra-rossa paleosol, and the presence of associated marine deposits at about $4 \mathrm{~m}$ all indicate that this ridge was 
deposited during the last interglacial period, i.e. Marine Isotope Stage (MIS) 5e. The primary morphology of the dune is well preserved, with a lee side facing towards the bank interior and large eolian foresets dipping towards the southwest (Fig. 6).

The orientation of the lee face of the dune and the dip of the foresets clearly show that the constituent particles originated from the outer platform to the northeast. Today, this outer platform is extremely narrow (Fig. 7), and does not seem extensive enough to support an ooid factory, even of the Joulters Cays type. However, the scalloped shape of the bank margin, which could be related to platform collapse (Mullins \& Hine, 1989; Mullins et al., 1991), and the truncation of middle Pleistocene deposits in the Boiling Hole area, just north of Gregory Town (Fig. 9), both suggest that the North Eleuthera bank has experienced a significant amount of recessive erosion since the late Pleistocene. Similar bank-margin retreats have been documented from the Cat Island platform (Freeman-Lynde \& Ryan, 1985) and from Silver, Navidad and Mouchoir Banks in the SE Bahamas (Mullins et al., 1992) for older geological periods. Furthermore, seismic data from the Bahamas/Blake Escarpment north of Little Bahama Bank (LBB) indicate about a $5 \mathrm{~km}$ retreat since the Early Cretaceous. It is not clear whether the recess of these bank margins results from a few major mass-wasting events or from a constant process of chipping away. In the former case, large-scale collapse of platform margins, well away from a plate boundary, would appear as a recent (i.e. late Pleistocene), if not an on-going phenomenon that could represent serious tsunami hazards for the low-lying coastal zones in the Caribbean and southeastern United States (H.T. Mullins, personal communication). Regardless, part of the large ooid accumulations exposed on the windward islands could be derived from shoals that covered an outer portion of the platform that no longer exists due to recessive erosion processes (Fig. 7).

\section{Ooid production on the bank side and exportation to the outer platform}


According to a third model, suggested to the first author by R.N. Ginsburg some years ago, ooids were formed on the bank side of the islands, transported eastward by tidal currents to the ocean side, and then back onto the islands by the trade-wind action. An illustration of this model can perhaps be observed near Lee Stocking Island (LSI, Exumas, Fig. 1). In this area, km-sized ooid shoals formed by flood-tidal delta bars and levees occur at the bankward end of inter-island channels (Fig. 10; Kendall et al., 1990; Gonzalez \& Eberli, 1997). Indeed, one might expect that ooids could be carried seaward by ebb currents, deposited on ocean-facing beaches by waves, and finally blown onto dunes by the prevailing easterly winds. However, the modern, ocean-facing beaches on LSI are composed of bioclastic sand likely derived from offshore reefs. In addition, ebb-tidal deltas do not occur at the seaward end of the channels (Fig. 10), indicating that sediments are either swept off to deeper depositional environments (Dill et al., 1989) or were confined to the tidal channel by a circular hydrodynamic pattern (Reeder \& Rankey, 2005). Trade winds further provide a persistent set-up by which water is piled up against the bank margin and flows through the inter-island gaps, preferentially augmenting the daily flood-tidal currents over the ebb-tidal currents. For example, Lily Bank on the northern edge of LBB (Hine, 1977) clearly shows a flood or bankward dominance of bedforms, and sand-body geometric features like bankward-oriented spillover lobes. Given an appropriate track, a hurricane could produce much stronger easterly flows that would transport lagoonal sediments eastward through the inter-island gaps and place these sediments in the windward environment for dune development. However, such an event is probably rare and highly unusual. Hurricanes pass by quickly, and there is simply not enough time to transport significant quantities of sand over long distances (at least several km, but probably tens of $\mathrm{km}$ ) in a 3-4 hour time frame. This model does not appear to be the solution to explain the presence of extensive Pleistocene oolites on the windward islands. 


\section{Bank-side production and eastward transport of ooids}

In the fourth and last model, ooids were formed on the bank interior and transported directly onto the islands by a westerly energy flux. The Boiling Hole section in northern Eleuthera (Fig. 11) represents a good illustration of such a case. At this location, oolitic limestones dating from the last interglacial (Kindler \& Hearty, 1995; Hearty, 1998) partly fill a large depression between two 20 m-high eolianites of middle Pleistocene age, and are capped by MIS 5a dunal deposits (Fig. 3B in Kindler \& Hearty, 1997). New observations at the SE end of this swale reveal that (1) the MIS 5e oolites consist of two shallowing-upward sequences including subtidal, beach and eolian deposits, separated by an erosional surface (Figs. 12 and 13), and (2) both beach and eolian bed sets dip towards the SW, i.e. the bank interior. Further, as already noted by Kindler \& Hearty (1995), the MIS 5e deposits include some peculiar ooids with a radial cortex (Fig. 14).

The dip of the beach beds clearly shows that the constituent grains of these sediments originated from the interior of the bank, to the southwest. The eolian strata dip in the same direction. However they are not foresets, as figured by earlier authors (Kindler \& Hearty, 1995; Hearty, 1998), but backsets draped over the pre-existing middle Pleistocene topography. Thus, their component particles were also brought up from the bank interior by a westerly flux, and not from the open ocean by the prevailing easterly winds, as previously interpreted. Further, the unusual occurrence of radial ooids (Fig. 14) in these deposits suggests a relatively low-energy production locus (Land et al., 1979; Flügel, 2004), thus strengthening a bank-side source for these deposits. The case is even clearer at Cotton Hole, $1 \mathrm{~km}$ to the northwest (Fig. 11), where bankward-dipping beach sediments exposed on the ocean-facing cliffs can be walked on all the way to the bank-facing shoreline of the island. The Boiling Hole outcrop thus validates the fourth model. Moreover, ooids were not carried eastward during a single and catastrophic depositional event, such as a storm or a northwesterly gale, 
but by a sustained westerly flux that lasted long enough for the shoreline to prograde significantly towards the southwest.

\section{CONCLUSIONS}

The response to Ginsburg's question about the curious occurrence of large oolite accumulations on the windward islands of GBB is the following. Most likely, ooids have been produced on a very narrow outer platform between the bank edge and the islands, as is the case today along the Yucatan Peninsula (Ward \& Brady, 1979), and were brought onto the islands by transport vectors (i.e. wind and waves) similar in orientation to those operating today. This model is supported by theoretical calculations. In addition, ooids may have been generated on a wide outer platform that has since disappeared due to recessive erosion. In some cases, e.g. the Boiling Hole area in Eleuthera, ooids have been formed on the bank side and transported by energy fluxes that were opposite to modern ones. The important point to keep in mind from this "ooid story", in particular from the fourth model, is that past sedimentary features may not necessarily be explained by the observation of modern processes, or in other words, that the present is not always a key to the past.

\section{ACKNOWLEGMENTS}

PK would like to thank again R.N. Ginsburg for accepting him as a post-doctoral student in his laboratory some 15 years ago, and for asking good questions. Many thanks also to F. Gischig and J. Metzger (University of Geneva) for their technical help, and to the Swiss National Science Foundation for supporting PK’s travel expenses to Salt Lake City (grant n 200020-107436). We further thank A. Strasser, H.T. Mullins and the editors for reviewing and revising our manuscript. 


\section{REFERENCES}

Bain, R.J. and Kindler, P. (1994) Irregular fenestrae in Bahamian eolianites: a rainstorm induced origin. J. Sed. Res., A64, 140-146.

Ball, M.M. (1967) Carbonate sand bodies of Florida and the Bahamas. J. Sed. Petrol., 37, 556-591.

Bathurst, R.B.G. (1975) Carbonate sedimentology and diagenesis, Elsevier, Amsterdam.

Boss, S.K. and Neumann, A.C. (1993) Impacts of Hurricane Andrew on carbonate platform environments, northern Great Bahama Bank. Geology, 21, 897-900.

Carew, J.L and Mylroie, J.E. (1987) A refined geochronology for San Salvador Island, Bahamas. In: Proceedings of the 3rd Symposium on the Geology of the Bahamas, (Ed. H.A. Curran) pp. 35-44, Bahamian Field Station, San Salvador.

Carew, J.L. and Mylroie, J.E. (2001) Quaternary carbonate eolianites of the Bahamas: useful analogs for the interpretation of ancient rocks? In: Modern and Ancient Carbonate Eolianites: Sedimentology, Sequence Stratigraphy, and Diagenesis (Eds. F.E. Abegg, D.B. Loope and P.M. Harris), SEPM Spec. Publ., 71, 33-45.

Dill, R.F., Kendall, C.G.St.C. and Shinn, E. (1989) Giant subtidal stromatolites and related sedimentary features. Field Trip Guidebook T373, 28th International Geological Congress, 33 pp.., American Geophysical Union, Washington.

Flügel, E. (2004) Microfacies of carbonate rocks, Springer Verlag, Berlin.

Freeman-Lynde, R.P. and Ryan, W.B.F. (1985) Erosional modification of Bahama escarpment. Geol. Soc. Am. Bull., 96, 481-494.

Ginsburg, R.N. (2005) Disobedient sediments can feedback on their transportation, deposition and geomorphology. Sed. Geol., 175, 9-18.

Gonzalez, R. and Eberli, G.P. (1997) Sediment transport and bedforms in a carbonate tidal inlet; Lee Stocking Island, Exumas, Bahamas. Sedimentology, 44, 1015-1030. 
Haak, A.B. and Schlager, W. (1989) Compositional variations in calciturbidites due to sealevel fluctuations, late Quaternary, Bahamas. Geol. Rundsch., 78, 477-486.

Halley, R.B. and Harris, P.M. (1979) Fresh-water cementation of a 1,000-year-old oolite. J. Sed. Petrol., 49, 969-988.

Harris, P.M. (1979) Facies anatomy and diagenesis of a Bahamian ooid shoal. Sedimenta VII, University of Miami, Florida.

Hearty, P.J. (1998) The geology of Eleuthera Island, Bahamas: a rosetta stone of Quaternary stratigraphy and sea-level history. Quatern. Sci. Rev., 17, 333-355.

Hearty, P.J. and Kaufman, D.S. (2000) Whole-rock aminostratigraphy and Quaternary sealevel history of the Bahamas. Quatern. Res., 54, 163-173.

Hearty, P.J. and Kindler, P. (1993) New perspectives on Bahamian geology: San Salvador Island, Bahamas. J. Coastal Res., 9, 577-594.

Hearty, P.J., Kindler, P., Cheng, H. and Edwards, L. (1999) A +20 m middle Pleistocene sea-level highstand (Bermuda and The Bahamas) due to partial collapse of Antarctic ice. Geology, 27, 375-378.

Hine, A.C. (1977) Lily Bank, Bahamas: history of an active oolite sand shoal. J. Sed. Petrol., 47, 1554-1581.

Hine, A.C. (1983) Relict sand bodies and bedforms of the Northern Bahamas: evidence of extensive early Holocene sand transport. In: Coated Grains (Ed. T.M. Peryt), pp. 116131, Springer Verlag, Berlin.

Kendall, C.G.St.C., Dill, R.F. and Shinn, E. (1990) Guidebook to the marine geology and tropical environments of Lee Stocking Island, The southern Exumas, Bahamas. KenDill Publishers, San Diego.

Kindler, P. (1992) Coastal response to the Holocene transgression in the Bahamas: episodic sedimentation versus continuous sea-level rise. Sed. Geol., 80, 319-329. 
Kindler, P. (1995) New data on the Holocene stratigraphy of Lee Stocking Island (Bahamas) and its relation to sea-level history. In: Terrestrial and Shallow Marine Geology of the Bahamas and Bermuda (Eds. H.A. Curran and B. White), Geol. Soc. Am. Spec. Pap., 300, p. 105-116

Kindler, P. and Hearty, P.J. (1995) Pre-Sangamonian eolianites in the Bahamas? New evidence from Eleuthera Island. Mar. Geol., 127, 73-86.

Kindler, P. and Hearty, P.J. (1996) Carbonate petrography as an indicator of climate and sea-level changes: new data from Bahamian Quaternary units. Sedimentology, 43, 381399.

Kindler, P. and Hearty, P.J. (1997) Geology of The Bahamas: architecture of Bahamian Islands. In: Geology and hydrogeology of carbonate islands (Eds. H.L. Vacher and T.M. Quinn), Dev. Sedimentol., 54, 141-160.

Kindler P. and Hearty. P.J. (2000) Elevated marine terraces from Eleuthera (Bahamas) and Bermuda: sedimentological, petrographic and geochronological evidence for important deglaciation events during the middle Pleistocene. Global Planet. Change, 24, 41-58.

Kindler, P. and Mazzolini, D. (2001) Sedimentology and petrography of dredged carbonate sands from Stocking Island (Bahamas). Implications for meteoric diagenesis and aeolianite formation. Palaeogeogr. Palaeoclimatol. Palaeoecol., 175, 369-379.

Kindler, P. and Strasser, A. (2000) Palaeoclimatic significance of co-occurring wind- and water-induced sedimentary structures in the last-interglacial coastal deposits from Bermuda and the Bahamas. Sed. Geol., 131, 1-7.

Land, L.S., Behrens, E.W. and Frishman, S.A. (1979) The ooids of Baffin Bay, Texas. J. Sed. Petrol., 49, 1269-1278.

Mackenzie, F.T. (1964) Bermuda Pleistocene eolianites and paleowinds. Sedimentology, 3, 52-64. 
McKee, E.D. and Ward, W.C. (1983) Eolian environment. In: Carbonate depositional environments (Eds. P.A. Scholle, D.G. Bebout and C.H. Moore), AAPG Mem., 33, 132170.

Mullins, H.T., Breen, N., Dolan, J., Wellner, R.W., Petruccione, J.L., Gaylord, M., Andersen, B., Melillo, A.J., Jurgens, A.D. and Orange, D. (1992) Carbonate platforms along the southeast Bahamas-Hispaniola collision zones. Mar. Geol., 105, 169-209.

Mullins, H.,T., Dolan, J., Breen, N., Andersen, B., Gaylord, M., Petruccione, J.L., Wellner, R.W., Melillo, A.J. and Jurgens, A.D. (1991) Retreat of carbonate platforms: response to tectonic processes. Geology, 19, 1089-1092.

Mullins, H.T. and Hine, A.C. (1989) Scalloped bank margins: beginning of the end for carbonate platforms? Geology, 17, 30-33.

Newell, N.D., Purdy, E.G. and Imbrie, J. (1960) Bahamian oolitic sand. J. Geol., 68, 481496.

Purdy, E.G. (1963) Recent calcium carbonate facies of the Great Bahama Bank. 2. Sedimentary Facies. J. Geol., 71, 472-497.

Reeder, S.L. and Rankey, E. (2005) Stuck on a spin cycle: interactions between tidal flows and ooid shoals, Bahamas. Abstracts with Programs, 37, 401.

Reijmer, J.J., Swart, P.K., Bauch, T., Otto, R., Reuning, L. Roth, S.,and Zechel, S. 2007. A reevaluation of facies variations on Great Bahama Bank 1: New Facies Maps of Western Great Bahama Bank. In: Perspectives in Sedimentary Geology: A Tribute to the Career of Robert Nathan Ginsburg, IAS Special Publication (Eds P.K. Swart, G.P. Eberli and J.A. McKenzie), In Press. Blackwell, Oxford.

Richter, D.K. (1983) Calcareous ooids: a synopsis. In: Coated Grains (Ed. T.M. Peryt), pp. 71-99, Springer Verlag, Berlin . 
Schlager, W. (1981) The paradox of drowned reefs and carbonate platforms. Geol. Soc. Am. Bull., 92, 197-211.

Scholle, P. A. and Ulmer-Scholle, D.S. (2003) A color guide to the petrography of carbonate rocks: grains, textures, porosity, diagenesis. AAPG Mem., 77, 474 pp.

Sealey, N.E. (1994) Bahamian landscapes. An introduction to the geography of the Bahamas, Media Publishing, Nassau, Bahamas.

Siewers, F.D. (2003) Oolite and coated grains. In: Encyclopedia of sediments and sedimentary rocks (Ed. G.V. Middleton), pp. 502-506, Kluiver Academic Press, Dordrecht.

Swart, P.K. , Reijmer, J.J. and Otto, R. (this volume) A Reevaluation of facies on Great Bahama Bank II: Variations in the $\delta^{13} \mathrm{C}, \delta^{18} \mathrm{O}$ and mineralogy of surface sediments. In: Perspectives in Sedimentary Geology: A Tribute to the Career of Robert Nathan Ginsburg, IAS Special Publication (Eds P.K. Swart, G.P. Eberli and J.A. McKenzie), In Press. Blackwell, Oxford.

Ward, W.C. and Brady, M.J. (1979) Strandline sedimentation of carbonate grainstones, Upper Pleistocene, Yucatan Peninsula, Mexico. Amer. Assoc. Petrol. Geol. Bull., 63, $362-369$. 


\section{FIGURE CAPTIONS}

Fig. 1: Geographical situation of the Great Bahama Bank (GBB). The occurrence of islands (Eleuthera, Cat, Exumas, Long) on the eastern margin of GBB is likely related to the prevailing easterly winds. JC = Joulters Cays, NPI = New Providence Island, TOTO = Tongue of the Ocean, SC = Schooners Cays.

Fig. 2: Vertically stacked eolianites (A, B and C) and paleosols (1 and 2) of middle Pleistocene age at The Cliffs, central Eleuthera. Eolianites form during interglacial highstands, whereas paleosols predominantly develop during glacial lowstands. Note large-scale eolian foresets in lower unit (white arrow) indicating that constituent particles were derived from the northeast. All carbonate units include mainly skeletal particles derived from offshore reefs. Cliff is $15 \mathrm{~m}$ high (people on the left-hand side for scale).

Fig. 3: Topographic map of East End Point, southern Eleuthera showing the NNW-SSE trending, middle Holocene ridge between Big Pond and the North Atlantic shoreline. The ridge crest is located at about $4 \mathrm{~km}$ to the west of the bank margin.

Fig. 4: Partial view of the East End Point oolitic ridge looking towards the south. The large, westward-dipping, eolian foresets disappear beneath modern, bioclastic, beach sands, indicating that (1) the dune was deposited when sea level was slightly lower than present, and that (2) there was an ooid factory to the east of the island. 
Fig. 5: Oolitic grainstone collected from the East End Point ridge (sample EL 201). Abundant superficial ooids, good particle preservation, and minor low-Mg calcite meteoric cement characterize this middle Holocene unit.

Fig. 6: View from the top (45 $\mathrm{m}$ at this particular location) of the Gregory Town ridge towards the west. This ridge consists of oolitic limestone of late Pleistocene age. Note preserved dune morphology, with the lee side facing the bank interior. Large westwarddipping foresets (arrow) further indicate that the constituent sedimentary particles originated from the east. Road cut is $4 \mathrm{~m}$ high.

Fig. 7: Satellite view of northern Eleuthera showing scalloped (i.e. convex bankward) margin. The extreme narrowness of the outer platform in this area is probably related to bankedge erosion or collapse. The missing part of the platform was probably the site of ooid production during MIS 5e. Image from: https://zulu.ssc.nasa.gov.

Fig. 8: Oolitic-peloidal grainstone collected from the Gregory Town ridge (sample EL 159). Note the greater abundance of normal ooids and meteoric sparry calcite cement compared to the younger East End Point oolite.

Fig. 9: Topographic map of the Boiling Hole - Glass Window area. The modern windward shoreline truncates a NW-SE trending eolian ridge of middle Pleistocene age, indicating that a substantial amount of regressive erosion occurred since that time (modified from the topographic map Eleuthera \#4 published by the Department of Lands and Surveys, Nassau; contour lines are in feet). 
Fig. 10: Oblique air photo of the southern Exumas showing Norman Ponds Cay (NPC) and Lee Stocking Island (LSI). Note extensive ooid shoal on the bankward side of the tidal channel between the two islands. Despite the presence of this ooid factory, beaches on the windward side of LSI are characterized by bioclastic sand. Photo courtesy Paul J. Hearty.

Fig. 11: Geologic map of the Boiling Hole area (modified from Kindler \& Hearty, 1997).

Fig. 12: View of the southeastern end of the Boiling Hole outcrop showing two stacked late Pleistocene oolites (units 2 and 3) onlapping a skeletal eolianite of middle Pleistocene age (unit 1). Unit 3 beach deposits (upper right-hand side) show low-angle cross beds that dip towards the southwest indicating that constituent particles were formed on and transported from the bank interior.

Fig. 13: Stratigraphic/sedimentological section logged on the southeastern end of the Boiling Hole site. In the setting column, s = subtidal, b = beach, e = eolian. Dots indicate sample location. 204 marks the location of sample EL 204 illustrated in Fig. 14.

Fig. 14: Radially coated ooid from late Pleistocene oolite at Boiling Hole (sample EL 204). Radial cortex suggests ooid formation occurred in a relatively low-energy setting. 


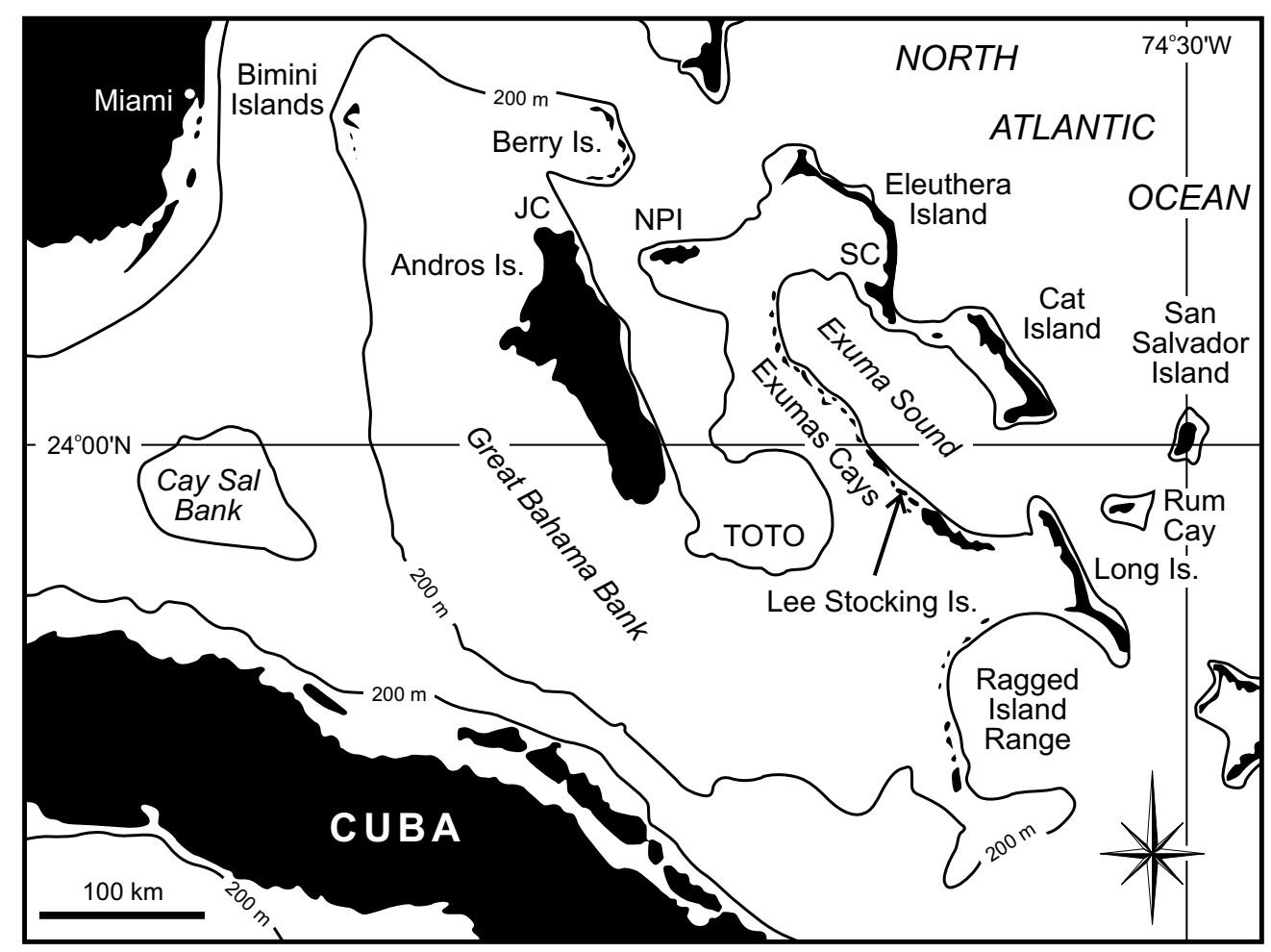

Fig. 1 


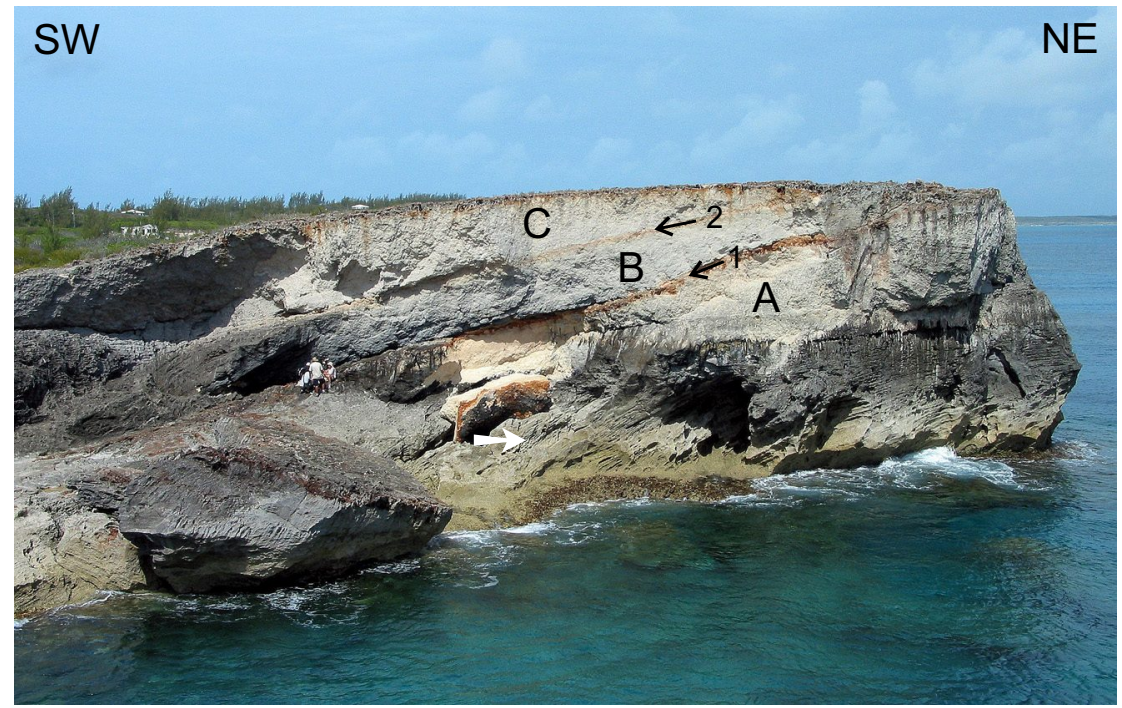

Fig. 2 


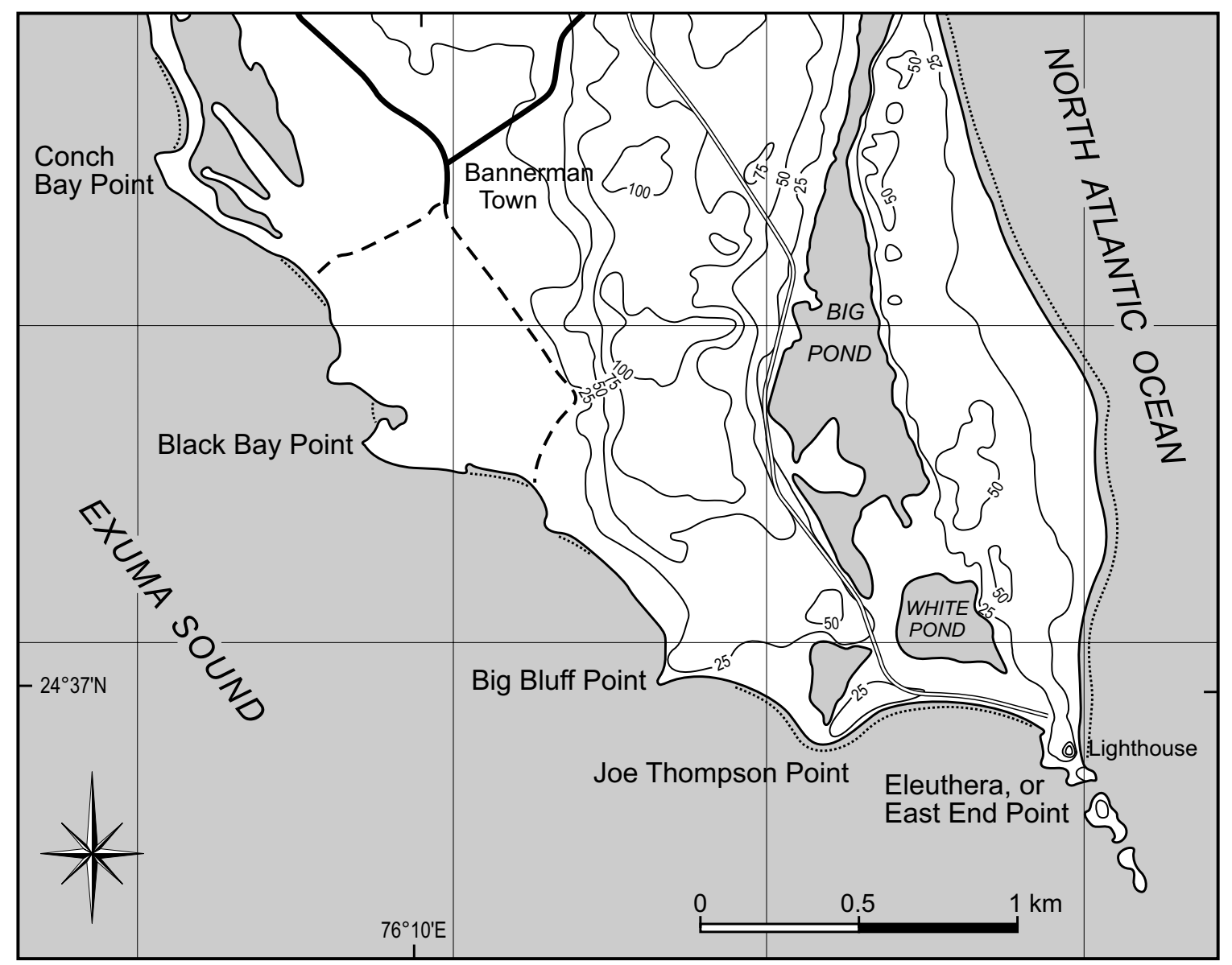

Fig. 3 


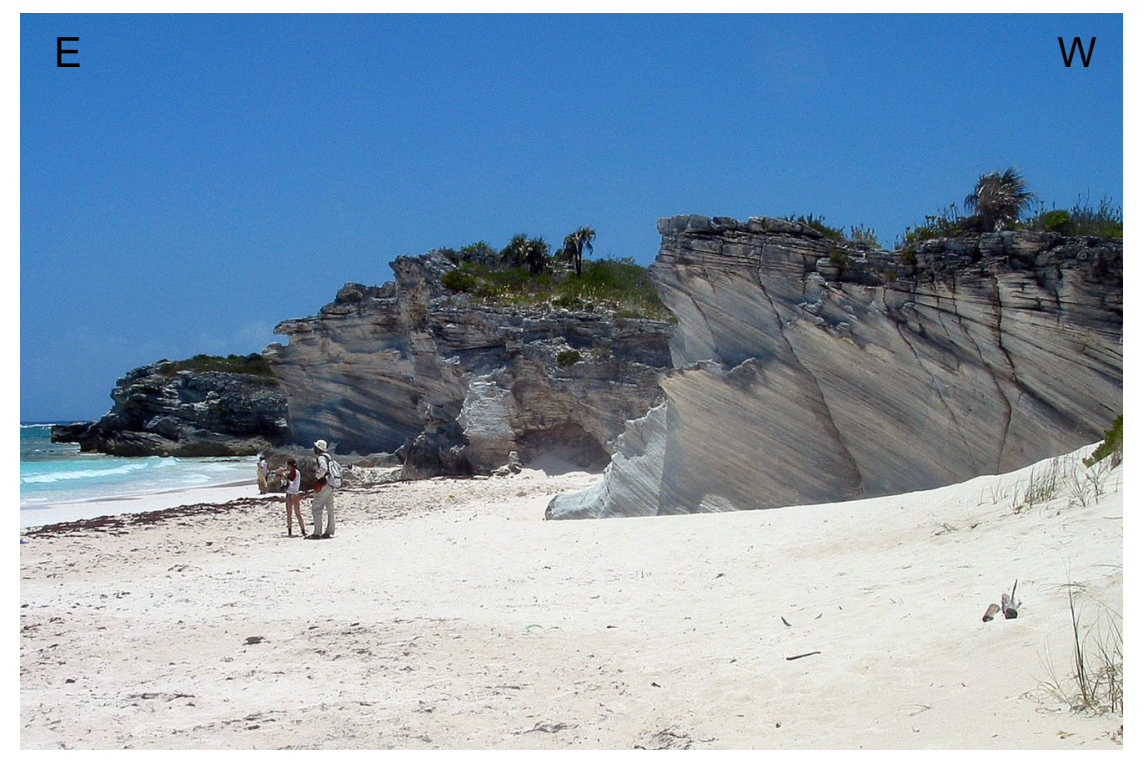

Fig. 4 


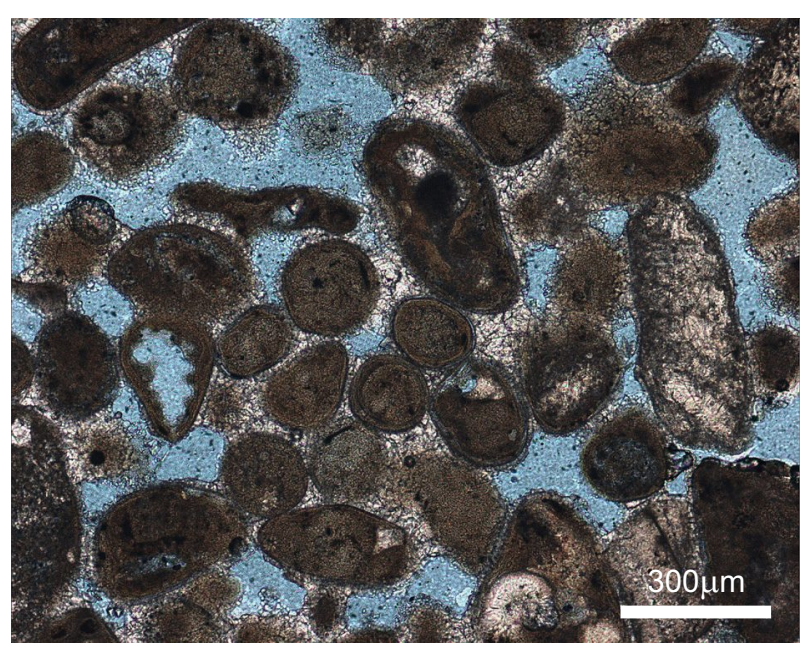

Fig. 5 


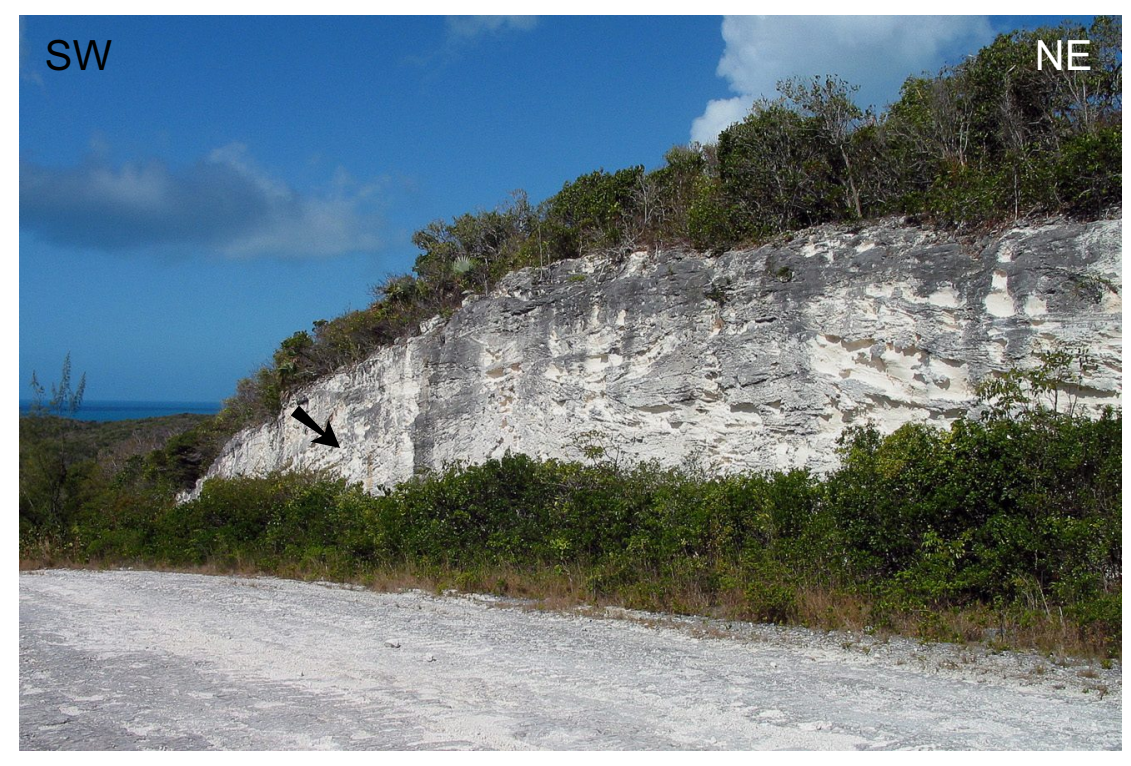

Fig. 6 


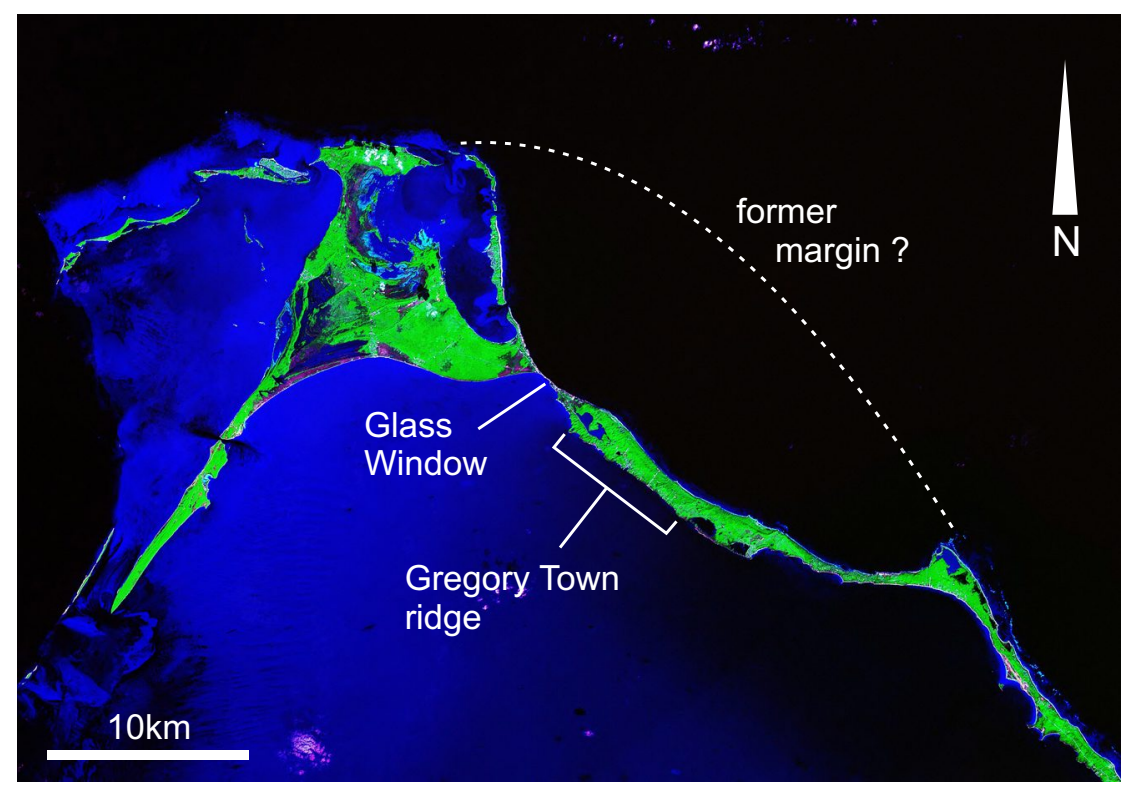

Fig. 7 


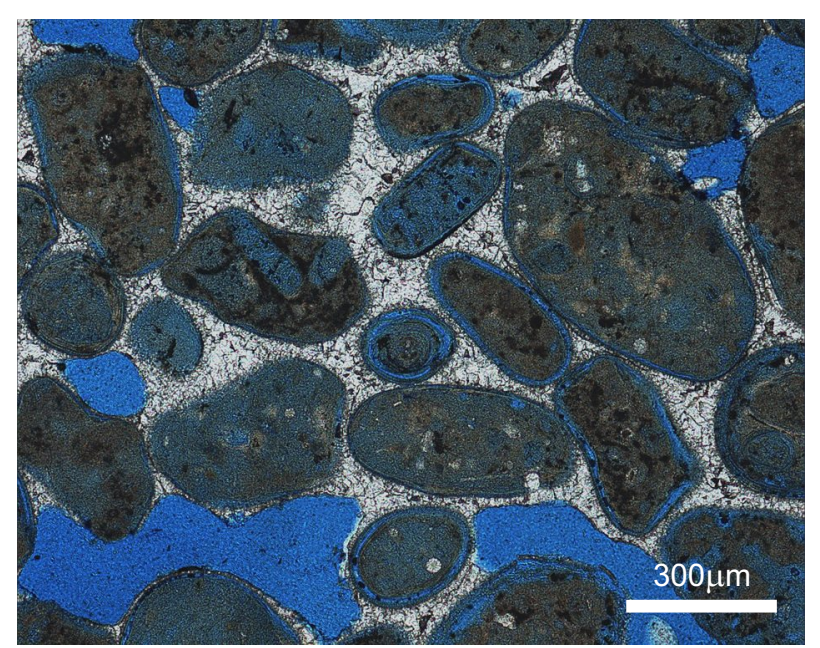

Fig. 8 




Fig. 9 


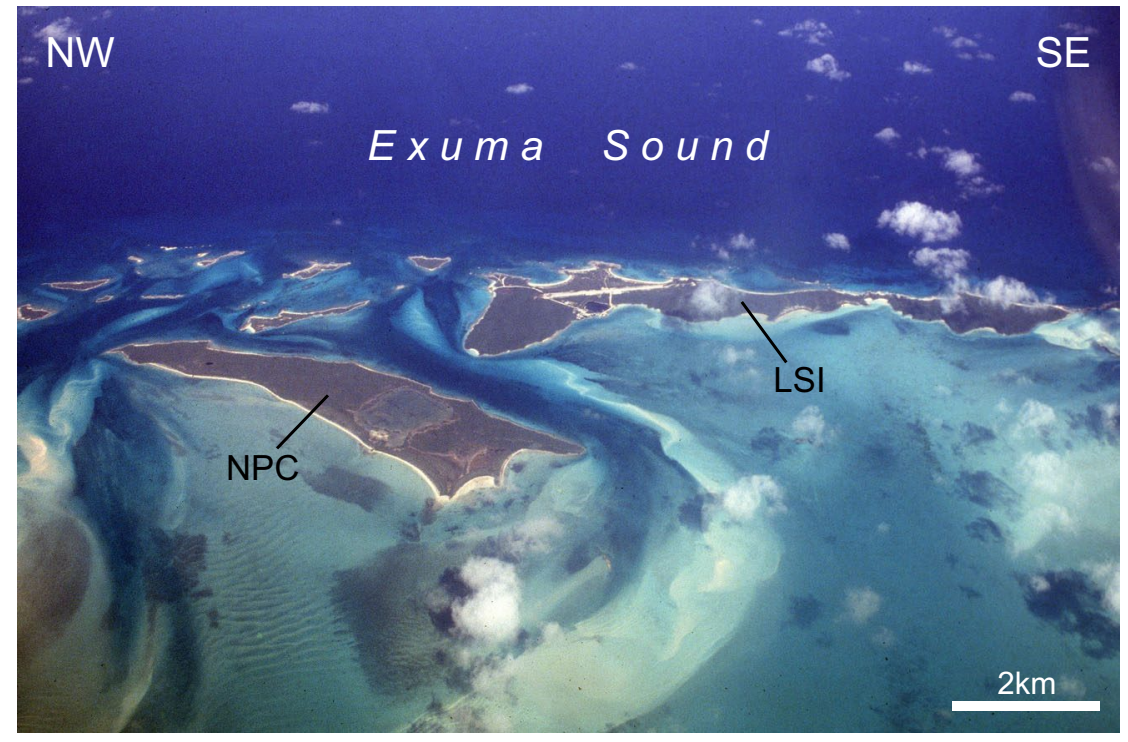

Fig. 10 




Fig. 11 


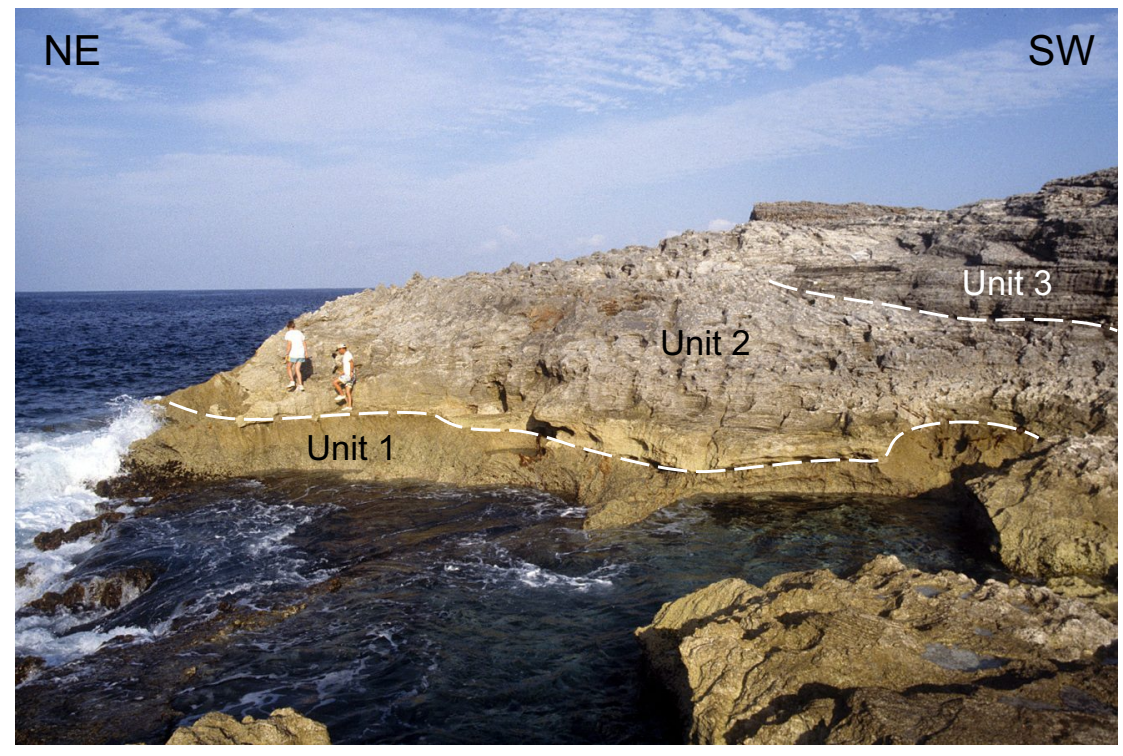

Fig. 12 


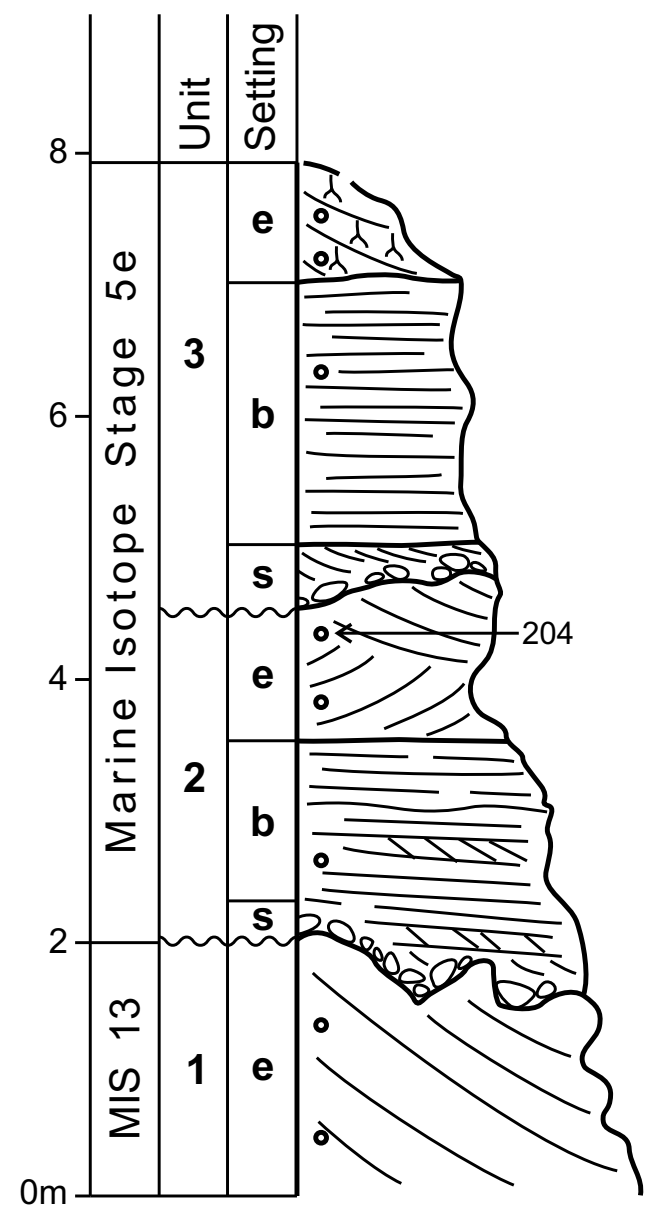

Fig. 13 


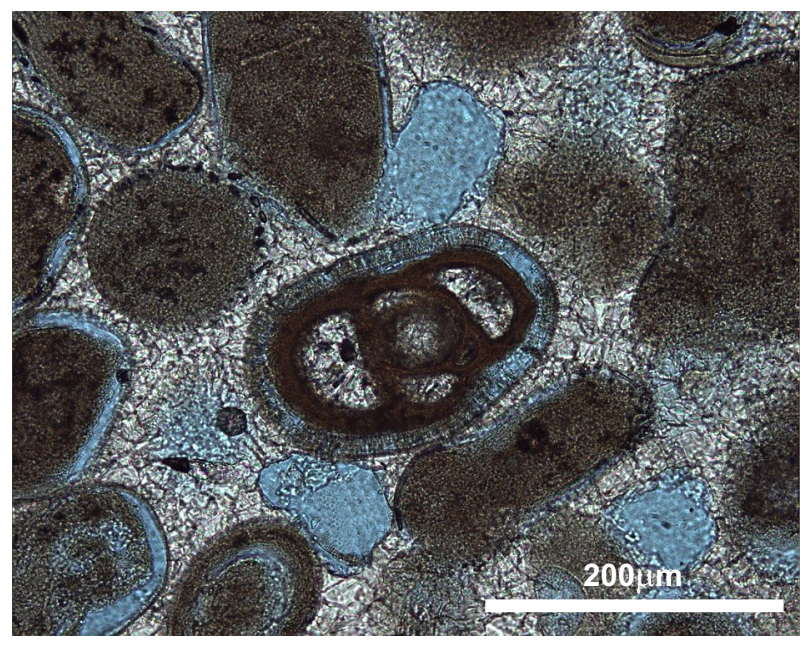

Fig. 14 